\title{
Malignant melanoma of the anal canal
}

\author{
B. C. MORSON AND H. VOLKSTÄDT \\ From the Research Department, St. Mark's Hospital, London
}

SYNOPSIS The clinical and pathological features of 15 cases of malignant melanoma of the anal canal are described.

It would appear from this study that these tumours arise from squamous epithelium lining that part of the anal canal at or just above the line of the anal valves.

Pack, Lenson, and Gerber (1952) in a review of 1,222 cases of malignant melanoma found that $1.5 \%$ were located in the ano-rectal region. Up to the end of 1960 reports of at least 157 cases have been found by us in the literature. However, there are few detailed accounts of the pathology of malignant melanoma of the ano-rectum, probably because few authors have experience of more than a few cases. Moreover, the very existence of malignant melanoma of the ano-rectum is not well known and some cases may have been mistakenly recorded as anaplastic squamous cell carcinoma or even anaplastic carcinoma of the rectum, for these tumours often present as rectal growths on clinical examination.

Moore (1857) described a malignant melanoma which first affected the verge of the anus and later appeared higher up the rectum. Two cases were described by Maier (1858) and by Virchow (1861) and a further one by Paneth (1883). Subsequent reports by Ball (1885), Tuffier (1888), SchmidtPeterson (1888), and Heller (1901) reveal a total of 25 cases described up to the end of the last century.

In the present century a further 132 cases have been found by us, making a total of 157 to the present time (for references see bibliography).

Of all these contributions few discuss pathogenesis in detail, but those of Lindner and Wood (1936), Braastad, Dockerty, and Dixon (1949) and Delaney, Scudamore, and Waugh (1954) give the best descriptions of the pathology of malignant melanoma of the anal canal.

Fifteen patients with malignant melanoma of the ano-rectum were treated at St. Mark's Hospital during the years 1938-1959. Dukes and Bussey (1947) described two of these which were also included in a brief survey of nine tumours by Morson (1960a).

Received for publication 10 November 1962.

\section{MATERIAL AND METHODS}

A review of all benign and malignant tumours of the ano-rectal region in the records of this hospital is being pursued and has revealed the present total of 15 cases of malignant melanoma of the anal canal seen during this 22-year period. However, 10 of these have been seen in the last 12 years, which perhaps indicates a greater awareness of the diagnosis.

In all but four of these patients an operation was carried out for removal of the primary tumour. The surgical specimens were prepared by cutting along the anterior aspect and stretching them out on a metal frame. The specimen was then photographed and the extent of local and lymphatic spread assessed by anatomical dissection and microscopy. Because of this routine method and the museum preservation of some specimens, it has been possible to make an accurate assessment of the exact site of origin of the primary tumour in the 11 cases treated by excision. In particular, the relationship of the tumour to the dentate line or line of the anal valves has been assessed as accurately as possible.

All the histological sections were stained with haematoxylin and eosin and the presence of melanin was confirmed by Fontana's ammoniacal silver method.

\section{CLINICAL FEATURES}

AGE The ages of the 15 patients varied from 41 to 75 with an average age of approximately 59 years. This is much the same as the age incidence of adenocarcinoma of the rectum and squamous cell carcinoma of the rectum and squamous cell carcinoma of the anal canal (Morson, 1960b).

SEX There were eight women and seven men. In squamous cell carcinoma of the anal canal there is a preponderance of women (Morson, 1960b), whereas adenocarcinoma of the rectum is commoner in men (Dukes and Bussey, 1958). However, Braastad et al. (1949) in their review of the literature report a 
large preponderance of men with malignant melanoma of the ano-rectal region.

PRESENTING SYMPTOMS All but two patients complained of rectal bleeding. Other symptoms, in order of frequency, included pain, prolapse, loss of weight, anal irritation and constipation.

DURATION OF SYMPTOMS This varied from three weeks to eight months, averaging four months.

SITE OF TUMOURS As judged by clinical examination, 11 of the tumours were regarded as occupying the lower third of the rectum and four as arising from the anal canal.

CLINICAL DIAGNOSIS In six patients there was a diagnosis of cancer of the rectum, three were diagnosed as 'piles', one as an epithelioma of the anal canal, and three as malignant melanoma, this diagnosis being apparent because of the obvious pigmentation of the tumours.

BIOPSY DIAGNOSIS In five of the 15 patients the correct diagnosis of malignant melanoma was made. All of these were obviously pigmented tumours. Five patients were diagnosed as cases of anaplastic carcinoma, four as anaplastic squamous cell carcinoma, and one as doubtful secondary carcinoma.

Recognition in a biopsy of a rare condition like malignant melanoma of the anal canal depends to some extent on the awareness of the observer that this is a site where such tumours occur. In amelanotic tumours the biopsy distinction from anaplastic rectal carcinoma or anaplastic squamous cell carcinoma may be impossible, although subsequent examination of the whole tumour should provide clues to the correct diagnosis. Fortunately, as far as any influence on surgical treatment is concerned, a report of an anaplastic malignant tumour is sufficient, for it would appear that excision of the rectum as practised for adenocarcinoma or squamous cell carcinoma of the ano-rectal region is the only treatment that offers any hope of prolonging life or adding to the comfort of the patient.

The distinction from anaplastic rectal carcinoma can be aided by mucin stains such as alcian blue which are often positive even in the most undifferentiated rectal tumours. The distinction from anaplastic squamous cell carcinoma may be impossible when reporting on a small biopsy specimen. Multinucleated and polymorphous giant cells are common in melanoma (Fig. 1), a feature which may be helpful in the differential diagnosis, for such cells are very exceptional in both rectal adenocarcinoma and squamous cell carcinoma of the anal canal.

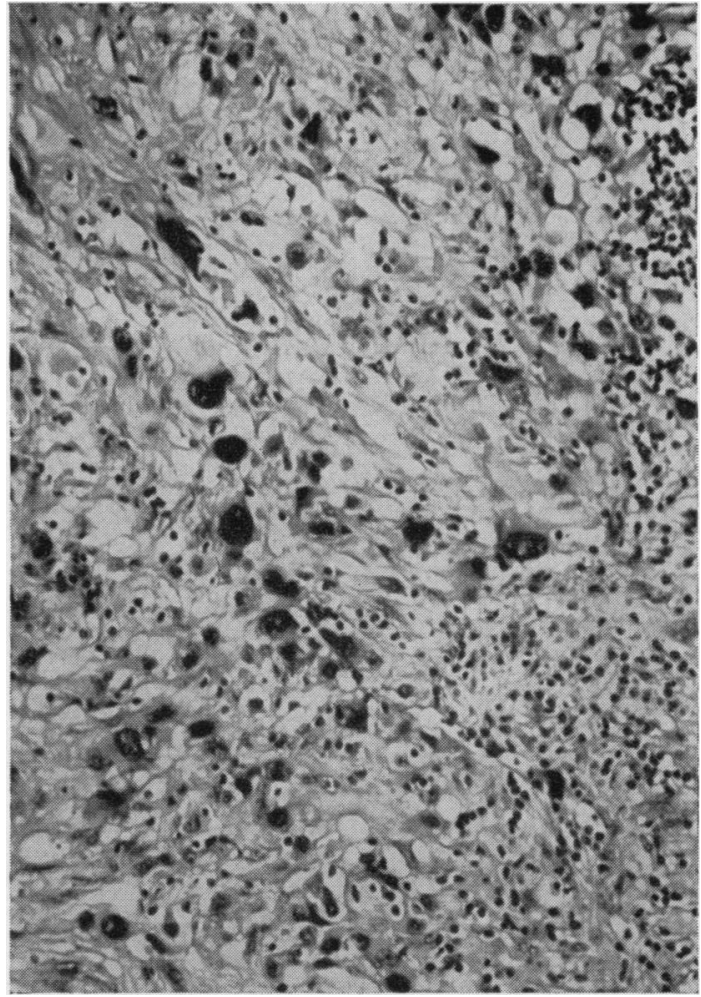

FIG. 1. Giant cells in a malignant melanoma of the anal canal. Haematoxylin and eosin $\times 150$.

\section{PATHOLOGY}

INCIDENCE During the 22-year period 1938 to 1959 a total of 3,535 cases of adenocarcinoma of the rectum, 122 patients with squamous cell carcinoma of the anus and anal canal, and 15 patients with malignant melanoma were seen at St. Mark's Hospital. This means that approximately one malignant melanoma of the anal canal is seen for every eight squamous cell carcinomas of the anus and anal canal and one for every 250 adenocarcinomas of the rectum.

GROSS APPEARANCES In the 11 operation specimens available for examination there were nine protuberant growths (Fig. 2), most of them very large, and two ulcerative lesions. However, one of the latter patients had had a previous local excision of a protuberant tumour at another hospital, where it was mistaken clinically for a thrombosed internal haemorrhoid. This tumour was the most heavily pigmented of the series. It also showed a few small secondary deposits of tumour in the rectal submucosa, one of which was heavily pigmented. Two other primary tumours were obviously pigmented by 


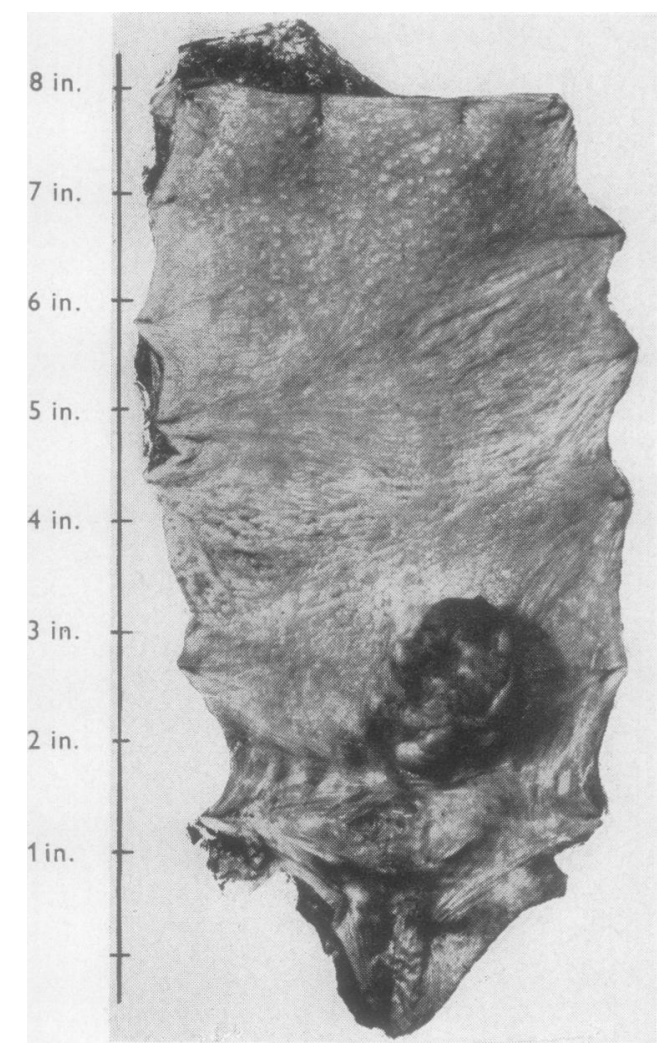

FIG. 2. Rectum and anal canal showing a protuberant pigmented growth lying on the posterior quadrant of the upper anal canal immediately' above the dentate line. naked-eye examination. In one of these, the only $\stackrel{\overrightarrow{0}}{\overrightarrow{5}}$
one in the series, the lymph node deposits were also heavily pigmented. The solitary growth of ulcerative $\overrightarrow{\vec{A}}$ type was by far the smallest tumour in the series, being only about $1 \mathrm{in}$. in diameter. The large size of the growths in this series is completely at variance with the experience of Braastad et al. (1949) that malignant melanomas of the anal canal tend to be small tumours.

One large protuberant growth was pedunculated, $\overrightarrow{0}$ being attached to the upper part of the anal canal $\overrightarrow{-}$ just above the dentate line by a broad-based pedicle. Immediately adjacent to this pedicle there were $a \stackrel{\rightarrow}{\circ}$ number of small wart-like projections which proved? on histological examination to be small primary $\vec{\sigma}$ tumours arising from the modified squamous $i v$ epithelium covering the anal valves and papillae. $\vec{N}$ All the other protuberant tumours in the series were sessile although some of the tumour mass projecting into the rectum appeared to be due to preferential upward submucous spread with re-eruption through the rectal mucous membrane.

POSITION OF PRIMARY TUMOUR The site of origin of $\stackrel{\mathscr{\omega}}{\mathcal{E}}$ the 11 excised tumours is given in Figure 3. All of them appeared to arise from the anal canal. Four lay entirely above the line of the anal valves and the remainder astride but mainly above this line.

ASSOCIATED PATHOLOGY In one specimen there was also a well-differentiated adenocarcinoma of the rectum, with two lymphatic metastases from the

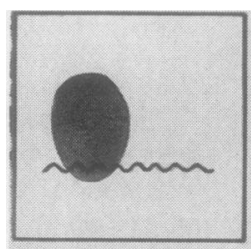

1.

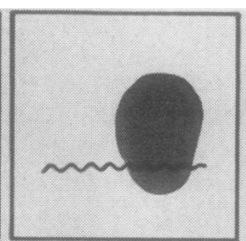

2.

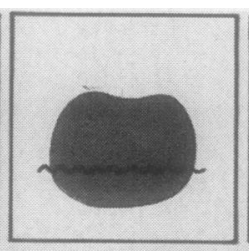

3.

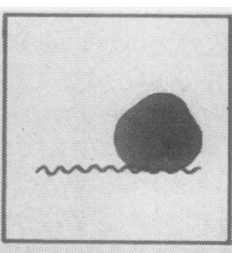

4.

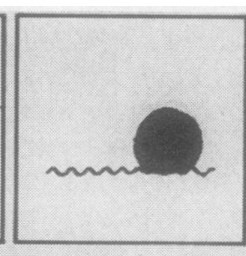

5.

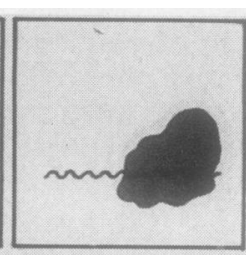

6.

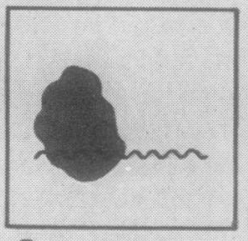

7.

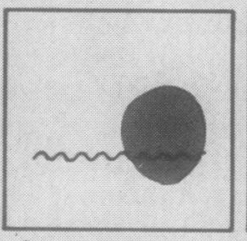

8.

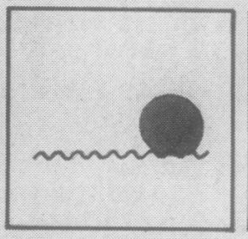

9.

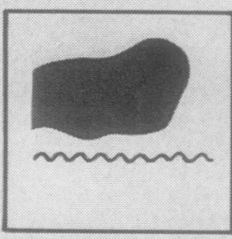

10.

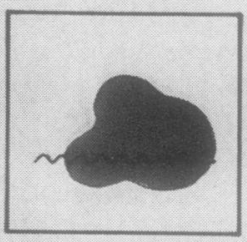

11.

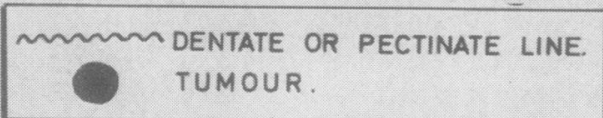

FIG. 3 . 
malignant melanoma of the anal canal in this specimen.

HISTOLOGY The tumours had a rather variable histological appearance. They were obviously highly invasive with a marked degree of pleomorphism and large numbers of mitotic figures. Some cells showed a 'squamoid' pattern and this was most marked in those tumours reported as 'anaplastic squamous cell carcinoma' on biopsy examination. But mostly the cells were polygonal in shape with an abundant eosinophilic cytoplasm. In three tumours there were areas with a tendency towards a spindle-cell sarcomatous pattern, but this was not a feature which gave any difficulty in the histological diagnosis. The tumour cells in three cases showed a very vacuolated cytoplasm, but this appearance did not compare with the vacuolation sometimes seen in anaplastic carcinoma of the rectum due to mucus secretion. Multinucleated and polymorphous giant cells were conspicuous in large numbers in four of the tumours. In five growths a solid alveolar arrangement of the tumour cells was common, this being particularly marked in one case which also showed less pleomorphism and fewer mitoses than the other tumours. However, many lymphatic metastases in the haemorrhoidal and inguinal glands were present and the patient died within three months of operation. The patient with the longest survival time in this series (three years and two months) had a typically pleomorphic polygonal cell melanoma containing numerous mitoses.

In 10 out of the 15 tumours varying amounts of melanin pigment were present, but in only three of these was the amount sufficient to be obvious on clinical examination and inspection of the tumour in the laboratory. Even then it was patchy in its distribution. In seven out of the 10 pigmented tumours the amount of melanin was very small in relation to the size of the growths. Allen and Spitz (1953) report that only two out of nine of their ano-rectal melanomas were pigmented and draw attention to the practical point that if reliance is placed on the finding of melanin for the diagnosis of melanocarcinomas of mucous membranes then about half of them will be missed.

In most cases the tumour was so large that all evidence of histogenesis at the microscopic level was destroyed. However, in three of the smaller growths there was clear evidence that the malignant melanoma was the result of proliferation of cells at the epidermo-dermal margin of simple squamous mucous membrane in the region of the anal valves (Fig. 4). Reference has already been made to the small wart-like lesions adjacent to the primary growth in one of the surgical specimens. These have

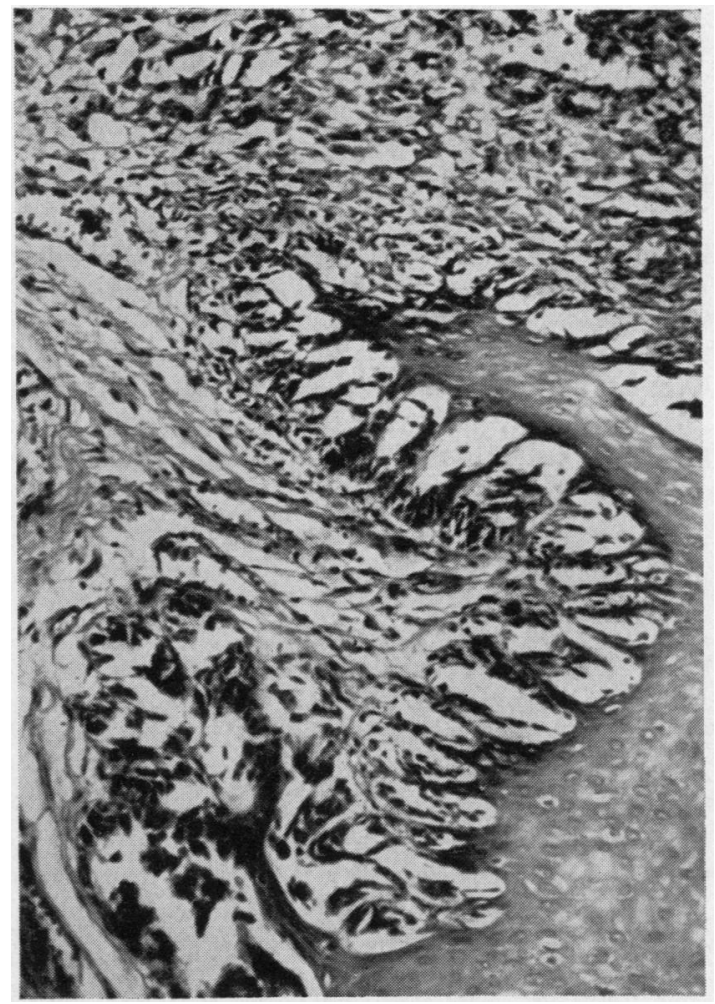

FIG. 4. Proliferating basal cells at the epidermo-dermal margin of squamous mucosa at the dentate line. Haemato$x y l i n$ and eosin $\times 50$.

the histology of small primary tumours arising from the basal layers of the squamous mucous membrane covering and immediately adjacent to the anal valves.

SPREAD Very extensive invasion of the tissues around the anal canal was a feature of all cases. However the direction of spread was predominantly upwards into the lower rectum, particularly in the submucous layer. This preferential upward spread is also characteristic of squamous cell carcinoma of the anal canal (Morson, 1960b). In one specimen multiple small submucous nodules of growth were present in the lower rectum. In two patients with very advanced disease, one of whom was inoperable, there were discrete small nodules of growth under the squamous mucous membrane of the anal canal below the line of the anal valves.

In seven out of the 11 operation specimens there were metastases in the superior haemorrhoidal group of lymph nodes. Four of these were $C_{1}$ cases and three $C_{2}$ cases as judged by Dukes' classification (Dukes, 1932). The number of lymphatic metastases varied from one to 17 , with an average of seven. 
Inguinal gland involvement as judged by both clinical and pathological observations was present in four of the patients who were treated by excision of the rectum. In three of these patients the inguinal glands were involved at the time of operation and were present synchronously with haemorrhoidal gland metastases. In one patient the involvement of the inguinal glands appeared two years after operation. In another inoperable case the patient presented clinically with inguinal gland enlargement. The inguinal gland direction of spread in malignant tumours of the anal canal generally appears at a later stage of the disease than haemorrhoidal node metastases (Morson, 1960b).

\section{TREATMENT AND PROGNOSIS}

Two patients were considered inoperable. One of these had clinical signs of widespread intraabdominal disease with ascites, oedema of the legs, and radiological evidence of metastases in both lungs. He died one month after admission to hospital. The second inoperable patient presented with greatly enlarged inguinal glands, a fungating mass protruding from the region of the left ischio-rectal fossa, and multiple bilateral pulmonary metastases. He died two months after admission with clinical evidence of further metastases in the liver, skin, and brain.

Laparotomy was performed on two patients. One had massive submucous infiltration in the rectum, very extensive growth in the pelvis, and liver secondaries. He died nine months after operation. The other showed diffuse peritoneal spread, multiple secondaries in the liver, and many obviously involved intra-abdominal glands. All deposits were black. This patient died four months after admission to hospital.

Eleven patients had an excision of the rectum and anal canal with permanent colostomies. In only five of these, however, was the operation regarded as radical in the sense that the surgeon felt that he had removed the whole of the primary growth and all known metastases. In the remaining six patients the surgeon knew that either the primary growth or some of the metastases had not been completely removed and these are therefore classified as palliative operations.

Two of the 15 patients in this series died within one month of admission to hospital. The survival time of the remaining 13 patients varied from two months to three years and two months, with an average survival time of approximately nine months.

The survival of the five patients who had a radical operation with removal of the primary growth and all known metastases varied from five months to three years and two months, with a average survival rate of $15 \frac{1}{2}$ months. In the patien $\widehat{\mathbb{B}}$ treated by a palliative operation the survival varied. from one to 18 months with an average survival timfe of only five months. In the whole series of 15 patien only one survived more than 18 months aft? diagnosis or operation. This was the only case of small tumour in the series, being about 1 in. i⿺ diameter, and there were no lymphatic metastases? in the operation specimen. Death occurred from metastases three years and two months after radical excision of the rectum and anal canal. The histologd of this tumour showed no special features, being typically pleomorphic type with numerous mitoses

The survival rate in malignant melanoma of the anal canal is so poor that these relatively smaib differences in prognosis have little more than academic interest. It would appear from this studg as well as from the prognosis of cases reported io the literature that the only hope of 'cure' in this type of anal canal tumour is diagnosis at a vert early stage of the disease. Berkley (1960) has described one patient who survived nearly six years after excision of the rectum before dying frorf secondary deposits.

\section{DISCUSSION}

Many accounts of malignant melanoma of the anos rectal region have described these tumours arising from the rectum proper. But this is int accurate, for it would appear from a study of the cases described here that they arise from the mido portion of the anal canal. It is true that clinical many of these growths appear to arise from the lower third of the rectum. This may, however, be based on a lack of awareness of the true boundarie of the anal canal. Alternatively the presence of the main mass of the tumour in the rectum in some patients could be due to preferential upward subsmucous spread with re-eruption into the recta lumen (Lindner and Wood, 1936; Braastad et at 1949).

It is likely that malignant melanoma of the and rectum usually arises from a squamous or closety related type of epithelium on or just above the line of the anal valves. A similar conclusion was reached by Braastad et al. (1949). In this series there was ne instance of rectal mucosa completely surrounding 9 primary tumour. If such a case occurred it would have to be established that the apparent primar.y tumour was not a manifestation of preferentiap upward submucous spread from a small primar in the region of the anal valves. However, it is stidi difficult to account for the pathogenesis of malignari melanoma high in the rectum as reported by 
Behrend and Behrend (1949) and Weston and Marren (1952). In such cases the possibility of the intestinal tumour being secondary to a small primary of the skin must be considered.

In the three tumours in this series which showed any clear evidence of histogenesis the malignant melanoma appeared to be the result of proliferation of basal cells at the epidermo-dermal margin of squamous epithelium covering the anal valves. In this connexion the case report by Fitzsimmons (1955) of a very early malignant melanoma arising in an hypertrophied anal papilla is of particular interest. Malignant melanoma of the peri-anal skin has never been seen at this hospital during a period of 30 years' careful documentation of all malignant tumours. Nor has there been any case which presented primarily as a tumour of the lower anal canal or anal margin.

If it is accepted that malignant melanoma of the ano-rectal region arises from squamous epithelium then the histogenesis of primary tumours entirely above the line of the valves can be explained by the recorded fact (Walls, 1958) that squamous mucous membrane is often found just above this line and is not necessarily the result of metaplasia. There is no evidence that melanocytes or melanophores are to be found in rectal mucosa. In melanosis coli the pigment-containing cells are macrophages and it is not even certain that this pigment is true melanin. It is doubtful whether squamous metaplasia of rectal mucosa ever occurs. When squamous epithelium is present in the anatomical rectum (Dukes, 1949; Drennan and Falconer, 1959) it is more likely to be either the result of continuous upward spread of squamous epithelium from the pecten over chronically ulcerated rectal mucosa or to congenital ectopia.

It is necessary to enquire why malignant melanoma of the ano-rectal region should arise from epithelium at or just above the line of the anal valves in preference to other parts of the anal canal, rectum, or peri-anal skin. There is some evidence that the epithelium lining this part of the anal canal is particularly exposed to chronic irritation. For example, it is at this level that internal haemorrhoids, especially if they are prolapsing and ulcerating, become covered by a squamous type of mucosa growing upwards from the pecten. Furthermore, the anal valves and papillae, because they protrude into the lumen of the anal canal, are particularly exposed to trauma during defaecation which may be a factor in the clinical conditions known as 'papillitis' and 'cryptitis' (Hughes, 1959). The hypothesis of chronic irritation has been invoked as a factor in the pathogenesis of malignant melanoma of the skin (Lewis, 1956). Recently Cade (1961) had denied that there is any evidence for this view, although Allen and Spitz (1953) believe that it may play a part in some cases.

We wish to thank the surgical staff of St. Mark's Hospital for permission to study their cases, also Mr. H. J. R. Bussey for his help and advice. The expenses of this investigation were defrayed out of a block grant to the Research Department of St. Mark's Hospital from the British Empire Cancer Campaign.

\section{REFERENCES}

Allen, A. C., and Spitz, Sophie (1953). Cancer (Philad.), 6, 1. Ball, C. B. (1885). Brit. med. J., $2,694$.

Behrend, M., and Behrend, A. (1949). Gastroenterology, 12, 142. Berkley, J. L. (1960). Dis. Colon. Rect., 3, 159.

Braastad, F. W., Dockerty, M. B., and Dixon, C. F. (1949). Surgery, $25,82$.

Cade, S. (1961). Ann. roy. Coll. Surg. Engl., 28, 331.

Delaney, L. T., Scudamore, H. H., and Waugh, J. M. (1954). Proc. Mayo Clin., 29, 416.

Drennan, J. M., and Falconer, C. W. A. (1959). J. clin. Path., 12, 175.

Dukes, C. E. (1932). J. Path. Bact., 35, 323. (1949). Ann. roy. Coll. Surg. Engl., 4, 90. , and Bussey, H. J. R. (1947). Brit. J. Cancer, 1, 30.

- - - (1958). Ibid., 12, 309.

Fitzsimmons, E. L. (1955). J. int. Coll. Surg., 23, 343.

Heller, H. (1901). Inaug.-Dissertation, Freiburg, in Baden 1895.

Hughes, E. S. R. (1959). In Diseases of the Colon and Anorectum, edited by R. Turell, ch. 44. Saunders, Philadelphia and London.

Lewis, C. W. D. (1956). Ann. roy. Coll. Surg. Engl., 19, 156.

Lindner, H. H., and Wood, W. Q. (1936). Brit. J. Surg., 24, 65.

Maier, R. (1858). Verhandlungen der naturforschenden Gesellschaft zu Frieburg im Breisgau, p. 515.

Moore, W. D. (1857). Lancet, 1, 290.

Morson, B. C. (1960a). Cancer of the Rectum, edited by C. E. Dukes, ch. 7. Livingstone, Edinburgh

(1960b). Proc. roy. Soc. Med., 53, 416.

Pack, G. T., Lenson, N., and Gerber, D. M. (1952). A.M.A. Arch. Surg., 65, 862.

Paneth, J. (1883). Langenbecks Arch. klin. Chir., 28, 179.

Schmidt-Petersen, J. (1888). Inaug.-Dissertation, Kiel.

Tuffier, . (1888). Arch. gén. Méd., 21, 28.

Virchow, R. L. K. (1861). Pathologie der Geschwuelste II Braunschweig p. 285.

Walls, E. W. (1958). Brit. J. Surg., 45, 504.

(1959). Proc. roy. Soc. Med., 52, suppl., p. 85.

Weston, S. D., and Marren, M. (1952). J. int. Coll. Surg., 17, 403.

BIBLIOGRAPHY OF MALIGNANT MELANOMA OF THE ANAL REGION, 1900-1961

Aghina, A. (1954). Boll. Centr. Diagn., Cura Tumori, 1, 121.

Allen, V. K. (1931). Trans. Amer. proctol. Soc., 32, 31.

Alp, C. (1956). J. int. Coll. Surg., 26, 83.

Bacon, H. E., and Pena, E. (1944). Clinics, 3, 457.

- and Tavenner, M. C. (1951). Amer. J. Surg., 82, 709.

Basu, A. K. (1950). Indian J. Surg., 12, 68.

Burns, F. J. (1960). Dis. Colon Rect., 3, 241.

Calabrese, L. (1960). Arch. Vecchi Anat. Pat., 33, 453.

Chalier, A., and Bonnet, P. (1912). Rev. Chir. (Paris), 46, 914.

- , (1913). Ibid., 47, 64, 235, 372, 563.

Chisholm, A. J. (1937). Colo. Med., 34, 570.

Churchman, J. W. (1918). Amer. J. med. Sci., 155, 639.

Clavel, C., and Garde, J. (1954). Lyon chir., 49, 734.

Coley, W. B., and Hoguet, J. P. (1916). Ann. Surg., 64, 206.

Christiani, G., Sokol, S., and Eguia, O. (1957). Pren. Méd. argent., $44,494$.

Divella, D. (1936). Riv. Chir. (Napoli), 2, 229.

Ferrand, B., Debaille, E., and Pelissier, G. (1954). Mém. Acad. Chir., $80,725$.

François-Dainville, (1904). Bull. Soc. anat. Paris, Ser. 6, 6, 39. 
Galard Paris, J. M., and Roca de Viñals, R. (1949). Med. clin. (Barcelona), 12, 118

Gerritzen, P. (1933). Langenbecks Arch. klin. Chir., 178, 400.

Goldblatt, M. E. (1925). J. Amer. med. Ass., 84, 1986.

Goldman, C., and Robillard, G. L. (1942). Amer. J. Surg., 57, 352.

- (1941). Trans. Amer. proctol. Soc., 42, 164.

Hertzler, A. E. (1923). Surg. Clin. N. Amer., 3, 1493.

Hume, A. H., and Marshall, S. F. (1957). Lahey Clin. Bull., 10, 174.

Ingle, S. R. (1935). Indian med. Gaz., 70, 266.

Kallet, H. E., and Saltzstein, H. C. (1933). Arch. Surg., 26, 633.

Kraker, D. A. (1924). Amer. J. Surg., 38, 271.

Landsman, A. A. (1933). Trans. Amer. proctol. Soc., 34, 65.

Lindner, H. H., and Wood, W. Q. (1936). Brit. J. Surg., 24. 65.

Locques, , (1908). Thése Montpelier.

Marino, A. W. M. (1934). J. Amer. med. Ass., 102, 203.

McEuen, H. B. (1930). Radiology, 14, 587.

McQuarrie, H. B. (1950). Postgrad. Med., 7, 402.

McQuire, E. R., and Lahey, L. J. (1924). Bull. Buffalo gen. Hosp., 2, 85.

Martin, J., and Reves, L. (1908). Bull. Soc. anat. Paris, 83, 289.

Mirajkar, V. R., and Sachdeva, Y. V. (1945). Indian J. Surg., 7, 50.

Moir, P. J. (1946). Brit. J. Radiol., 19, 217.

Müller, O. (1947). Acta chir. scand., 96, 39.
Neale, R. M., and Briggs, J. D. (1953). Calif. Med., 78, 311. Ohin, A. J. (1960). Missouri Med., 57, 1140.

Oppenheim, A., and O'Brien, J. P. (1950). Amer. J. Surg., 79, 302. 음 Owen, A. K. (1924). Amer. J. Roentgenol., 11, 335.

Pack, G. T., Gerber, D. M., and Scharnagel, I. M. (1952). Ann. Surg 136, 905.

- , and Martins, F. G. (1960). Dis. Colon. Rect., 3, 15.

Pennisi, G. (1959). Rass. int. Clin. Ter., 39, 411.

Percesepe, E., and Claudio, F. (1959). Rif. med., 73, 1194.

Probstein, J. G. (1957). A.M.A. Arch. Surg., 75, 253.

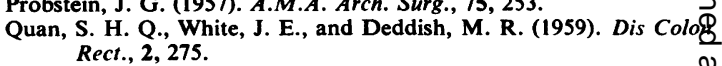

Raven, R. W. (1950). Amer. J. Surg., 79, 85.

Roberts, D. I. (1956). Brit. med. J., 1, 903.

Rosenberg, A. E. (1950). Amer. J. Surg., 79, 193.

Rosser, C. (1951). J. Fla. med. Ass., 38, 247.

Sandner, E. (1904). Inaug.-Dissertation, Erlangen.

Siebenhaar, J. G. (1909). lbid.

Smith, N. D., and Broders, A. C. (1935). Surg. Gynec. Obstet., 60,

Tuffier, . (1888). Arch. gén. Méd., 21, 28.

Venturo, R. C., and Miller, H. (1957). Amer. J. Proctol., 8, 56.
Weston, S. D., and Marren, M. (1952). J. int. Coll. Surg., 17, 403. $\vec{\sigma}$

Yaker, D. N. (1951). Amer. J. Surg., 81, 94. 